ISSN 0103-8478

\title{
Increasing levels of phytase in diets formulated with reduced available phosphorus content supplied to male and female broilers
}

\author{
Níveis crescentes de fitase em dietas formuladas com reduzido teor de fósforo disponível, \\ fornecidas a frangos de corte machos e fêmeas
}

\author{
Luciana de Paula Naves $^{\mathrm{I}}$ Paulo Borges Rodrigues ${ }^{\mathrm{I}}$ Levy do Vale Teixeira ${ }^{\mathrm{I}}$ \\ Antônio Gilberto Bertechini ${ }^{\mathrm{I}}$ Renata Ribeiro Alvarenga ${ }^{\mathrm{I}}$ \\ Verônica Maria Pereira Bernardino ${ }^{\mathrm{I}}$ Luziane Moreira dos Santos $^{\mathrm{I}}$ \\ Yuri Pereira Efrem Natividade ${ }^{\mathrm{I}}$
}

\section{ABSTRACT}

The reduction of the available phosphorus $\left({ }_{a v} P\right)$ content in the broiler diet must be followed by the supplementation of adequate phytase. One experiment was conducted with broilers from 15 to 28 days of age to determine the level of necessary phytase when the mashed diet is formulated with $0.213 \%$ of ${ }_{a v} P$ to enable the results of performance, tibia ash content, and calcium (Ca) utilization similar to those determined for birds fed with diet formulated to meet their nutritional requirements. Thus, 120 broilers were distributed in $(4+1) \times 2$ factorial arrangement corresponding to four deficient diets in ${ }_{a v} P(0.213 \%)$ supplemented with phytase $\left(0 ; 750 ; 1,500\right.$ or 2,250FTU $\left.\mathrm{kg}^{-1}\right)$ plus one positive control diet without phytase $\left(0.426 \%\right.$ of $\left.{ }_{a v} P\right)$, supplied to male and female broilers. Males showed better performance and higher $P$ retention. Decrease in the ${ }_{a v} P$ content of the diet without phytase use worsened the performance, tibia ash content, and Ca retention; however, these parameters were improved gradually with the increase of the phytase level in the diet. Regardless of sex, using $2,250 \mathrm{FTU} \mathrm{kg}^{-1}$, it is possible to reduce the $P$ to $0.213 \%$ without impairing performance, tibia ash content, and Ca retention; in addition to reducing the ${ }_{\text {tota }} P$ excretion in $56.75 \%$ and improving its utilization in $38.58 \%$.

Key words: aviculture, bone ash, enzyme, metabolism, performance, phytate.

RESUMO

A redução do teor de fósforo disponível $\left(P_{\text {disp }}\right)$ na dieta de frangos deve ser acompanhada de adequada suplementação da fitase. Um experimento foi conduzido com frangos de corte, no período de 15 a 28 dias de idade, para determinar o nível de fitase necessário quando a ração farelada é formulada com 0,213\% de $P_{\text {disp }}$ para permitir resultados de desempenho, teor de cinzas na tíbia e aproveitamento do cálcio (Ca) semelhantes ao determinado para aves alimentadas com uma dieta formulada para atender suas exigências nutricionais. Desse modo, 120 frangos foram distribuídos em esquema fatorial (4+1) x2, correspondendo a quatro rações deficientes em $P_{\text {disp }}(0,213 \%)$ suplementadas com fitase (0; 750; 1.500 ou 2.250FTU $\mathrm{kg}^{-1}$ ) mais uma ração controle positivo sem fitase $\left(0,426 \%\right.$ de $\left.P_{\text {disp }}\right)$, fornecidas a frangos machos e fêmeas. Os machos apresentaram melhor desempenho e maior retenção de $P_{\text {total }}$. A redução do teor de $P_{\text {disp }}$ da dieta sem o uso de fitase piorou o desempenho, o teor de cinzas ósseas e a retenção do $\mathrm{Ca}$, todavia, esses parâmetros foram gradativamente melhorados com o aumento do nível de fitase na ração. Independente do sexo, ao utilizar 2.250FTU $\mathrm{kg}^{-1}$, é possível reduzir o teor de $P_{\text {disp }}$ para $0,213 \%$ sem prejudicar o desempenho, teor de cinzas na tíbia e a retenção do Ca, além de reduzir a excreção do $P_{\text {total }}$ em $56,75 \%$ e melhorar seu aproveitamento em 38,58\%.

Palavras-chave: avicultura, cinza óssea, desempenho, enzima, fitato, metabolismo.

\section{INTRODUCTION}

The main idea of using phytase in the diet for broilers is based on the reduction in the content of available phosphorus $\left({ }_{\mathrm{av}} \mathrm{P}\right)$ accompanied by the inclusion of this enzyme. With this, it is expected that the ${ }_{\mathrm{av}} \mathrm{P}$ content present in the diet, added to the content of phytate $\mathrm{P}\left({ }_{\text {phy }} \mathrm{P}\right)$ made available by the catalytic action of the phytase, meets the $P$ requirement of the bird (HAN et al., 2009). The industry related to broiler nutrition, normally has recommended the phytase supplementation with an inclusion level between 500 and 1,000 units of phytase activity (FTU) $\mathrm{kg}^{-1}$ of diet (BERTECHINI, 2012). According to JENDZA et al. (2006), 500FTU kg-1 are equivalent to the addition of $0.12 \%$ inorganic $\mathrm{P}$ in the diet. SHAW et al. (2011), in

'Departamento de Zootecnia, Universidade Federal de Lavras (UFLA), CP 3037, 37200-000, Lavras, MG, Brasil. E-mail: luciana.naves@hotmail.com.*Autor para correspondência. 
turn, reported that it is possible to reduce $\mathrm{P}$ in the diet formulation in $0.16 \%$ using $1,000 \mathrm{FTU} \mathrm{kg}^{-1}$. These values of equivalence represent good results; but with the constant progress of the techniques of commercial production of phytase, the price of the enzyme has decreased, arousing the interest of evaluating higher rates of inclusion of phytase so that the avP content in the broiler diet can be reduced even more resulting in lower cost with feeding birds and lower excretion of $\mathrm{P}$ in the environment (MENEGHETTI et al., 2011).

The use of inclusion levels above of 1,000FTU $\mathrm{kg}^{-1}$ of diet have been evaluated for the broilers of the commercial strain Cobb $500^{\circledR}$ (MANANGI \& COON, 2008; MENEGHETTI et al., 2011; WALK et al., 2013). However, most of the recent researches have been conducted only with male broilers, necessitating further studies to evaluate whether there is an influence of the bird sex. Therefore, this study was conducted with male and female broilers Cobb $500^{\circledR}$, in the period from 15 to 28 days of age, to determine the level of phytase that should be utilized when the diet is formulated with only $0.213 \%$ of $\mathrm{P}$. For this, will be considered the phytase level which will allow to improve the $\mathrm{P}$ retention, in addition to maintain the performance, tibia ash content and utilization of the calcium (Ca) similar to determine for broilers fed with a positive control diet.

\section{MATERIALS AND METHODS}

One experiment was conducted in the Aviculture Sector of the Department of Animal Science of the Federal University of Lavras, Brazil. The experimental design was completely randomized, in a $(4+1) \times 2$ factorial arrangement, with four diets equally deficient in $\mathrm{P}$ P supplemented with increasing levels of 6-phytase synthesized by Aspergillus oryzae $\left(0 ; 750 ; 1,500\right.$ and $2,250 \mathrm{FTU} \mathrm{kg}^{-1}$ of diet $)$ plus one positive control diet without phytase, formulated according to the nutritional recommendations of ROSTAGNO et al. (2005), supplied to male and female broilers.

Each one of the five experimental diets was used in the mashed physical form, and was evaluated in three replications of four birds each, totaling 60 birds for each sex. Evaluating the effect of sex of birds is part of the objective of this research. Moreover, the use of male and female birds within a same cage (mixed housing) could increase the coefficient of variation of the experiment; thus, the sex was considered a factor within the factorial design to minimize the variation between the repetitions of the same treatment, promoting an experiment with a smaller mean square error.

Thus, 60 males and 60 females of chicks Cobb $500^{\circledR}$ were acquired at one day of age, sexed, and raised in a masonry shed up to 14 days of age, receiving basal diet formulated to meet their nutritional requirements (ROSTAGNO et al., 2005). On the 15 th day of age, birds were weighed individually and transferred to cages (experimental units with dimensions $50 \times 50 \times 50 \mathrm{~cm}$ ) in a metabolism room, so that the experimental units presented initial average weight of broilers similar to one another $(0.465 \mathrm{~kg}$ $\pm 0.002)$. The room was provided with constantly illumination (24 hours of light maintained by incandescent lamps of 100 watts) and the temperature was maintained between 22 and $26^{\circ} \mathrm{C}$. Each cage was provided with one pressure-type drinker, one individual gutter-type feeder with edge, and one tray for the collection of excreta. Experimental diets (Table 1) and water were supplied ad libitum in the period from 15 to 28 days of age.

The total experimental period comprised 13 days, ten of which were for adaptation to the facilities and experimental diets, followed by three days (RODRIGUES et al., 2005) of total collection of excreta (SIBBALD \& SLINGER, 1963). Feed intakes (FI) in the total period (from 15 to 28 days of age of the broilers) and in the collection period (from 25 to 28 days of age of the broilers) were calculated. Weight gain (WG) of the broilers was calculated in the total period and the feed conversion (FC) was calculated by dividing FI by WG.

The total collection of excreta was performed daily in the morning, so that the excreta of an experimental unit was collected in identified plastic bags and stored in freezer until the last day of collection, when the samples were homogenized and then 400 grams of each sample was pre-dried in an oven at $55^{\circ} \mathrm{C}$ during 72 hours. The dry matter, $\mathrm{Ca}$ and ${ }_{\text {total }} \mathrm{P}$ contents were determined in the excreta and diets according to methods of number 934.01, 935.13 and 965.17, respectively (AOAC, 2005). Balance and retention of the $\mathrm{Ca}$ and ${ }_{\text {total }} \mathrm{P}$ were calculated based on the dry matter. Retention coefficient of $\left({ }_{\text {Ret }} \mathrm{C}\right)$ of the nutrient was calculated by the equation ${ }_{\text {Ret }} \mathrm{C}$ $(\%)=[$ (nutrient intake - absolute excretion of the nutrient)/nutrient intake] x100. Moreover, at the end of the experiment, three birds per replication were slaughtered for the removal of the left tibia, which was subsequently striped off its flesh, dried at $105^{\circ} \mathrm{C}$, scoured with ethyl ether and incinerated at $600^{\circ} \mathrm{C}$, determining the ash content (method 942.05 of the AOAC, 2005). 
Table 1 - Composition and nutrient contents of the experimental diets on an as-fed basis.

\begin{tabular}{|c|c|c|c|}
\hline Ingredient $(\%)$ & Positive control diet ${ }^{1}$ & Negative control diet ${ }^{2}$ & $\begin{array}{l}\text { Negative control diet supplemented with } \\
\text { phytase }^{3} 750 / 1,500 / 2,250\end{array}$ \\
\hline Corn & 59.620 & 60.486 & 60.486 \\
\hline Soybean meal & 33.529 & 33.371 & 33.371 \\
\hline Soybean oil & 3.161 & 2.868 & 2.868 \\
\hline Salt & 0.482 & 0.482 & 0.482 \\
\hline L-lysine $\mathrm{HCl}$ 98\% & 0.167 & 0.170 & 0.170 \\
\hline DL-methionine $99 \%$ & 0.229 & 0.228 & 0.228 \\
\hline L-threonine $98,5 \%$ & 0.035 & 0.035 & 0.035 \\
\hline Mineral premix ${ }^{4}$ & 0.050 & 0.050 & 0.050 \\
\hline Vitamin premix ${ }^{5}$ & 0.040 & 0.040 & 0.040 \\
\hline Choline chloride $60 \%$ & 0.045 & 0.045 & 0.045 \\
\hline Calcitic limestone & 0.874 & 1.610 & 1.610 \\
\hline Dicalcium phosphate & 1.719 & 0.565 & 0.565 \\
\hline Inert (kaolin) & 0.0500 & 0.0500 & $0.0425 / 0.0350 / 0.0275$ \\
\hline 6-phytase & 0 & 0 & $0.0075 / 0.0150 / 0.0225$ \\
\hline \multicolumn{4}{|l|}{ 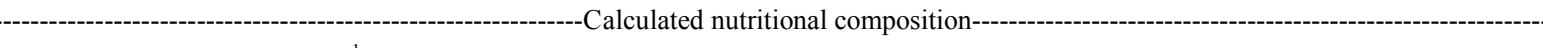 } \\
\hline Metabolizable energy $\left(\mathrm{kcal} \mathrm{kg}^{-1}\right)$ & 3,050 & 3,050 & 3,050 \\
\hline Crude protein $(\%)$ & 20.12 & 20.12 & 20.12 \\
\hline Calcium $(\%)$ & 0.855 & 0.855 & 0.855 \\
\hline Total phosphorus (\%) & 0.639 & 0.426 & 0.426 \\
\hline Available phosphorus (\%) & 0.426 & 0.213 & 0.213 \\
\hline Phytate phosphorus (\%) & 0.213 & 0.213 & 0.213 \\
\hline Activity of the 6-phytase ${ }^{3}$ & 0 & 0 & $750 / 1,500 / 2,250$ \\
\hline
\end{tabular}

${ }^{1}$ Diet formulated to meet the nutritional requirements of broilers of 15 to 28 days of age (ROSTAGNO et al., 2005). ${ }^{2}$ Diet deficient in available phosphorus. ${ }^{3}$ Enzymatic supplementation expressed in FTU kg ${ }^{-1}$ of diet. ${ }^{4}$ Provided per $\mathrm{kg}$ of diet: $55 \mathrm{mg} \mathrm{Zn}$; $48 \mathrm{mg}$ Fe; $10 \mathrm{mg}$ Cu; $78 \mathrm{mg} \mathrm{Mn} ; 0.70 \mathrm{mg}$ I; $0.18 \mathrm{mg}$ Se. ${ }^{5}$ Provided per kg of diet: $4.8 \mathrm{mg}$ vit. $\mathrm{B}_{2} ; 8,000 \mathrm{UI}$ vit. $\mathrm{A} ; 2,000 \mathrm{UI}_{\mathrm{Iit}} \mathrm{D}_{3} ; 1.2 \mathrm{mg}$ vit. $\mathrm{B}_{1} ; 2.4 \mathrm{mg}$ vit $\mathrm{B}_{6} ; 10.8 \mu \mathrm{g}$ vit. $\mathrm{B}_{12} ; 0.024 \mathrm{mg}$ biotin; $0.64 \mathrm{mg}$ folic acid; $11.6 \mathrm{mg}$ pantothenic acid; $1.92 \mathrm{mg}$ vit. $\mathrm{K}_{3} ; 16.2 \mathrm{UI}$ vit. E.

The data were subjected to variance analysis utilizing the software SAS (2004). Models of regression $(\mathrm{P}<0.05)$ were utilized to evaluate the level of phytase supplementation. The significance of broiler sex was evaluated by the F test $(\mathrm{P}<0.05)$. Moreover, the positive control diet was compared with the other experimental diets by Dunnett's test $(\mathrm{P}<0.05)$.

\section{RESULTS AND DISCUSSION}

There was no interaction $(\mathrm{P}>0.05)$ between the phytase level in the diet and the sex of birds for all performance parameters (Table 2). However, there was isolated effect of the sex $(\mathrm{P}<0.01)$, so that the males showed $10.26 \%$ bigger FI, $15.17 \%$ greater $\mathrm{WG}$ and $4.52 \%$ better FC, corroborating to MENDES et al. (2004), who reported that male broilers usually present better performance than females when reared under the same conditions.

The increase of the phytase level in the diet affected $(\mathrm{P}<0.05$ and $\mathrm{P}<0.01$, respectively), the FI and WG of the broilers in a quadratic manner, estimating greater FI and WG with the use of 1,069 and $1,401 \mathrm{FTU}_{\mathrm{kg}}{ }^{-1}$ of diet, respectively. Already the FC of the broilers decreased $(\mathrm{P}<0.05)$ linearly with the increasing supplementation of phytase, with an improvement of up to $3.85 \%$ in this parameter with the use of $2,250 \mathrm{FTU} \mathrm{kg}^{-1}$ of diet. Similarly, FUKAYAMA et al. (2008) also verified quadratic effects for FI and WG and decreasing linear effect for FC in male broilers from 1 to 20 days of age fed with diets deficient in ${ }_{\mathrm{av}} \mathrm{P}(0.273 \%)$ without phytase or supplemented with 500,750 or $1,000 \mathrm{FTU} \mathrm{kg}^{-1}$ of diet. The quadratic effect of the phytase level in the diet on the FI and WG is probably due to the fact that, with lower inclusion levels of phytase, the broilers tend to consume more feed to compensate the reducing of the $\mathrm{P}$ in the feed, and thus they gain more weight. However, with the inclusion of higher phytase levels, there are a lot releasing of the phytate P from feed, which may cause a nutritional imbalance that reduces the FI and WG of the broilers.

Concerning the positive control diet, there was no difference $(\mathrm{P}>0.05)$ for $\mathrm{FI}$; but, there was difference $(\mathrm{P}<0.05)$ for $\mathrm{WG}$ and $\mathrm{FC}$. Broilers fed with 
Table 2 - Performance (in the period from 15 to 28 days of age) and tibia ash content (at 28 days of age) of broilers fed with diets deficient in available phosphorus $\left.{ }_{\text {av }} \mathrm{P}\right)$ supplemented with increasing levels of phytase.

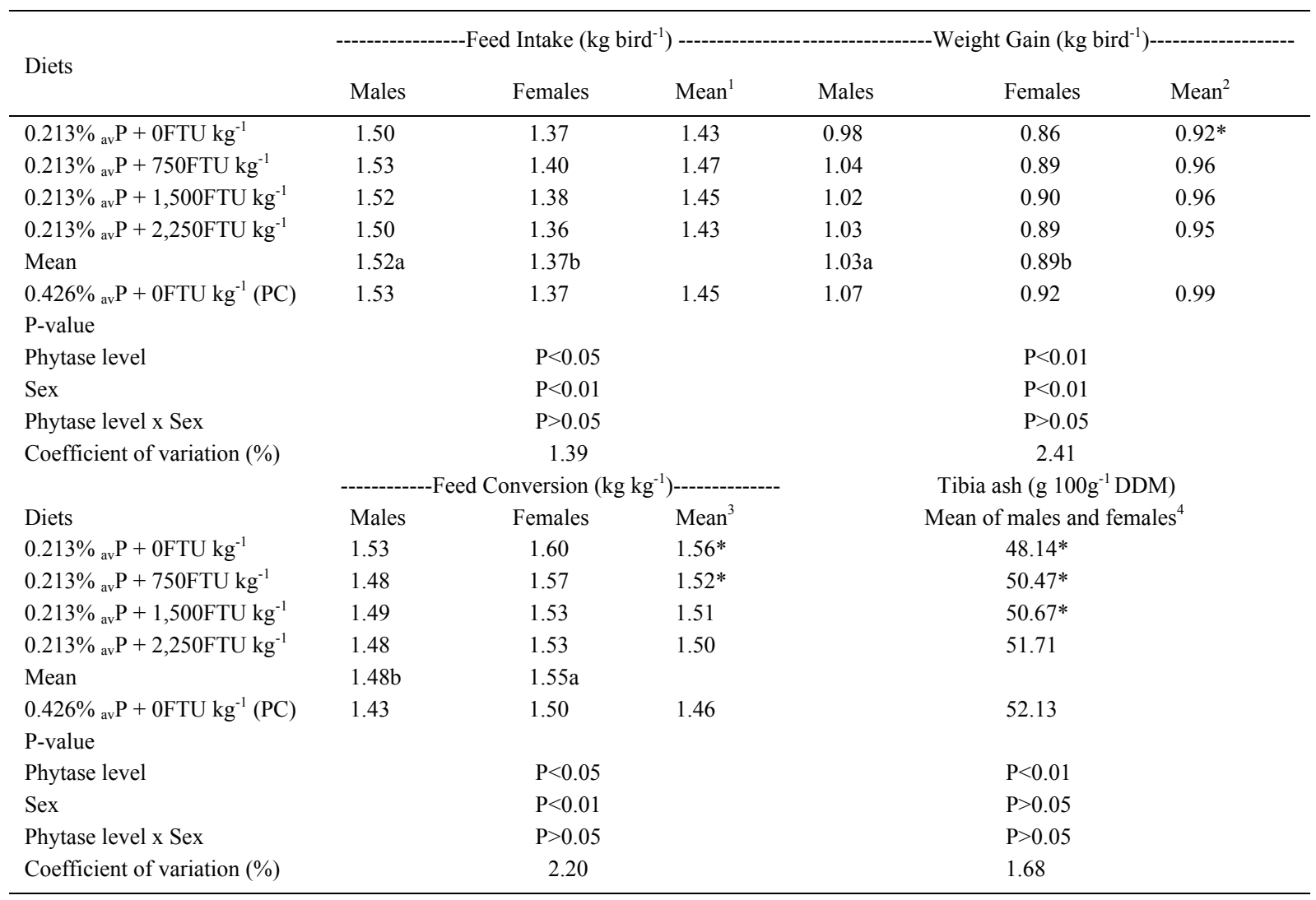

DDM: defatted dry matter. PC: positive control diet. Means with different letters, in the row, differ by the $\mathrm{F}$ test $(\mathrm{P}<0.05)$. ${ }^{*} \mathrm{Differs}$ from positive control diet by Dunnett's test $(\mathrm{P}<0.05)$.

${ }^{1}$ Feed intake $=-0.00002259 \mathrm{x}^{2}+0.04832 \mathrm{x}+1433.3250\left(\mathrm{R}^{2}=0.82\right) .{ }^{2}$ Weight gain $=-0.00002430 \mathrm{x}^{2}+0.06809 \mathrm{x}+919.65\left(\mathrm{R}^{2}=0.92\right) .{ }^{3} \mathrm{Feed}$ conversion $=-0.00002520 \mathrm{x}+1.55305\left(\mathrm{R}^{2}=0.84\right) .{ }^{4}$ Tibia ash $=0.00146 \mathrm{x}+48.61169\left(\mathrm{R}^{2}=0.87\right)$.

diet containing $0.213 \%$ P without phytase presented worsening of $7.75 \%$ in $\mathrm{WG}$, indicating that this diet did not supply $\mathrm{P}$ at an amount enough for the adequate development of the birds, but when phytase was utilized at levels as from $750 \mathrm{FTU} \mathrm{kg}^{-1}$, the ${ }_{\text {phy }} \mathrm{P}$ present in the vegetable ingredients of the diet was hydrolyzed by the enzyme at amount enough to prevent damage in the WG of the birds. However, only the diets deficient in ${ }_{\text {av }} \mathrm{P}$ containing 1,500 or $2,250 \mathrm{FTU} \mathrm{kg}^{-1}$ promoted $\mathrm{FC}$ similar to the observed for broilers from the positive control group. Nevertheless, the recommendation of the phytase level in the diet formulation should also consider an adequate bone mineralization (SAKOMURA \& ROSTAGNO, 2007).

There was no interaction $(\mathrm{P}>0.05)$ between the phytase levels and the bird sex, nor isolate effect $(\mathrm{P}>0.05)$ from sex for the tibia ash content (Table 2). However, the increase of the phytase level improvement linearly $(\mathrm{P}<0.01)$ this bone parameter. These results corroborate to SANTOS et al. (2008) and HAN et al.
(2009) who also observed improvement in the bone mineralization of broiler fed diets deficient in $\mathrm{P}$, but supplemented with phytase.

Furthermore, it was observed that only using 2,250FTU $\mathrm{kg}^{-1}$ of diet, the deposition of mineral matter in the tibia was similar to that determined for the broilers from the positive control group. Contrarily, FUKAYAMA et al. (2008) verified that 750FTU kg-1 was enough to prevent reduction in bone mineralization; however, the decrease of the ${ }_{\text {av }} \mathrm{P}$ content in this diet was of only $36 \%$, which is inferior to the value evaluated in this research $(50 \%$ of requirement). Besides, in the experiment of FUKAYAMA et al. (2008), diets contained $5.5 \%$ of defatted rice bran, increasing the content of ${ }_{\text {phy }} \mathrm{P}$ in the diet, which might have increased the catalytic efficiency of phytase because there was more substrate to be catalyzed.

There was no interaction $(\mathrm{P}>0.05)$ between the level of phytase and sex for the balance and retention of $\mathrm{Ca}$ (Table 3). However, males 
consumed and excreted $(\mathrm{P}<0.01)$ more $\mathrm{Ca}$, which can be explained by the greater FI that they presented (Table 2), associated with the fact of that the sex did not affect $(\mathrm{P}>0.05)$ the utilization of this mineral (Table 3). Similarly to what was verified for FI, the phytase level affected of quadratic manner $(\mathrm{P}<0.01)$ the $\mathrm{Ca}$ intake, with the highest value estimated for the diet with $1,222 \mathrm{FTU} \mathrm{kg}^{-1}$. The Ca excretion was reduced linearly $(\mathrm{P}<0.01)$ in $14.13 \%$ with the use of 2,250FTU $\mathrm{kg}^{-1}$ of diet, which is related to the linear improvement $(\mathrm{P}<0.01)$ in the Ca utilization promoted by the increasing levels of enzyme in the diet.

The broilers feed diet without phytase, formulated with reduced content of ${ }_{\text {av }} \mathrm{P}$, presented

Table 3 - Balance and retention coefficient of calcium and total phosphorus (in dry matter) of broilers, in the period from 25 to 28 days of age, fed diets deficient in available phosphorus $\left({ }_{\text {av }} \mathrm{P}\right)$ supplemented with increasing levels of phytase.

\begin{tabular}{|c|c|c|c|c|c|c|}
\hline \multirow[b]{2}{*}{ Diets } & \multicolumn{3}{|c|}{--------------Calcium intake $\left(\mathrm{g}\right.$ bird $\left.^{-1}\right)$------------- } & \multicolumn{3}{|c|}{ 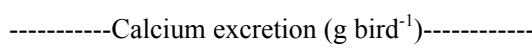 } \\
\hline & Males & Females & Mean $^{1}$ & Males & Females & Mean $^{2}$ \\
\hline $0.213 \%{ }_{\mathrm{av}} \mathrm{P}+0 \mathrm{FTU} \mathrm{kg}{ }^{-1}$ & 3.71 & 3.25 & $3.48^{*}$ & 2.28 & 1.99 & $2.14 *$ \\
\hline $0.213 \%{ }_{\text {av }} \mathrm{P}+750 \mathrm{FTU} \mathrm{kg}^{-1}$ & 3.87 & 3.41 & 3.64 & 2.20 & 1.99 & $2.09 *$ \\
\hline $0.213 \%{ }_{\text {av }} \mathrm{P}+1,500 \mathrm{FTU} \mathrm{kg}{ }^{-1}$ & 3.88 & 3.44 & 3.66 & 2.08 & 1.86 & 1.97 \\
\hline $0.213 \%$ av $\mathrm{P}+2,250 \mathrm{FTU} \mathrm{kg}^{-1}$ & 3.75 & 3.32 & $3.53 *$ & 1.95 & 1.72 & 1.84 \\
\hline Mean & $3.82 \mathrm{a}$ & $3.39 \mathrm{~b}$ & & $2.08 \mathrm{a}$ & $1.88 \mathrm{~b}$ & \\
\hline $0.426 \%{ }_{\text {av }} \mathrm{P}+0 \mathrm{FTU} \mathrm{kg}{ }^{-1}(\mathrm{PC})$ & 3.87 & 3.54 & 3.71 & 1.87 & 1.82 & 1.85 \\
\hline \multicolumn{7}{|l|}{ P-value } \\
\hline Phytase level & \multicolumn{3}{|l|}{$\mathrm{P}<0.01$} & \multicolumn{3}{|l|}{$\mathrm{P}<0.01$} \\
\hline Sex & \multicolumn{3}{|l|}{$\mathrm{P}<0.01$} & \multicolumn{3}{|l|}{$\mathrm{P}<0.01$} \\
\hline Phytase level x Sex & \multicolumn{3}{|l|}{$\mathrm{P}>0.05$} & \multicolumn{3}{|l|}{$\mathrm{P}>0.05$} \\
\hline \multirow[t]{2}{*}{ Coefficient of variation (\%) } & 2.42 & & & 4.42 & & \\
\hline & \multicolumn{3}{|c|}{ Calcium retention coefficient $(\%)^{3}$} & \multicolumn{3}{|c|}{------Total phosphorus intake $\left(\mathrm{g} \mathrm{bird}^{-1}\right)-$} \\
\hline Diets & \multicolumn{3}{|c|}{ Mean of males and females } & Males & Females & Mean $^{4}$ \\
\hline $0.213 \%$ av $\mathrm{P}+0 \mathrm{FTU} \mathrm{kg}{ }^{-1}$ & \multicolumn{3}{|c|}{$38.38 *$} & 1.90 & 1.65 & $1.77 *$ \\
\hline $0.213 \%{ }_{\mathrm{av}} \mathrm{P}+750 \mathrm{FTU} \mathrm{kg}^{-1}$ & \multicolumn{3}{|c|}{$42.49 *$} & 1.99 & 1.79 & $1.89 *$ \\
\hline $0.213 \%{ }_{\text {av }} \mathrm{P}+1,500 \mathrm{FTU} \mathrm{kg}{ }^{-1}$ & \multicolumn{3}{|c|}{$46.15^{*}$} & 1.93 & 1.74 & $1.84 *$ \\
\hline $0.213 \%$ av $\mathrm{P}+2,250 \mathrm{FTU} \mathrm{kg}{ }^{-1}$ & \multicolumn{3}{|c|}{47.72} & 1.86 & 1.62 & $1.74 *$ \\
\hline Mean & & $2.12 \mathrm{a}$ & $1.89 \mathrm{~b}$ & \\
\hline $0.426 \%{ }_{\text {av }} \mathrm{P}+0 \mathrm{FTU} \mathrm{kg}{ }^{-1}(\mathrm{PC})$ & \multicolumn{3}{|c|}{50.11} & 2.91 & 2.66 & 2.78 \\
\hline \multicolumn{7}{|l|}{ P-value } \\
\hline Phytase level & \multicolumn{3}{|c|}{$\mathrm{P}<0.01$} & \multicolumn{3}{|c|}{$\mathrm{P}<0.05$} \\
\hline Sex & \multicolumn{3}{|c|}{$\mathrm{P}>0.05$} & \multicolumn{3}{|c|}{$\mathrm{P}<0.01$} \\
\hline Phytase level x Sex & \multicolumn{3}{|c|}{$\mathrm{P}>0.05$} & & $\mathrm{P}>0.0$ & \\
\hline Coefficient of variation (\%) & & 5.42 & & & 4.29 & \\
\hline & ------Tot & lorus excr & g bird $\left.{ }^{-1}\right)------$ & --Total p & orus reten & efficient (\%)-- \\
\hline Diets & Males & Females & Mean $^{5}$ & Males & Females & Mean $^{6}$ \\
\hline $0.213 \%{ }_{\text {av }} \mathrm{P}+0 \mathrm{FTU} \mathrm{kg}{ }^{-1}$ & 0.87 & 0.79 & $0.83 *$ & 54.46 & 52.04 & $53.25^{*}$ \\
\hline $0.213 \%{ }_{\text {av }} \mathrm{P}+750 \mathrm{FTU} \mathrm{kg}^{-1}$ & 0.75 & 0.75 & $0.75^{*}$ & 63.82 & 58.41 & $61.12^{*}$ \\
\hline $0.213 \%{ }_{\mathrm{av}} \mathrm{P}+1,500 \mathrm{FTU} \mathrm{kg}{ }^{-1}$ & 0.76 & 0.70 & $0.73 *$ & 60.67 & 58.97 & $59.82 *$ \\
\hline $0.213 \%$ av $\mathrm{P}+2,250 \mathrm{FTU} \mathrm{kg}^{-1}$ & 0.67 & 0.63 & $0.65^{*}$ & 63.73 & 63.48 & $63.61^{*}$ \\
\hline Mean & $0.91 \mathrm{a}$ & $0.87 b$ & & $58.11 \mathrm{a}$ & $55.37 \mathrm{~b}$ & \\
\hline $0.426 \%{ }_{\mathrm{av}} \mathrm{P}+0 \mathrm{FTU} \mathrm{kg}{ }^{-1}(\mathrm{PC})$ & 1.52 & 1.49 & 1.50 & 47.84 & 43.95 & 45.90 \\
\hline P-value & & & & & & \\
\hline Phytase level & & $\mathrm{P}<0.01$ & & & $\mathrm{P}<0.0$ & \\
\hline Sex & & $\mathrm{P}<0.01$ & & & $\mathrm{P}<0.0$ & \\
\hline Phytase level x Sex & & $\mathrm{P}>0.05$ & & & $\mathrm{P}>0.0$ & \\
\hline Coefficient of variation (\%) & & 3.77 & & & 2.76 & \\
\hline
\end{tabular}

Means with different letters, in the row, differ by the $\mathrm{F}$ test $(\mathrm{P}<0.05)$. PC: positive control diet. *Differs from positive control diet by Dunnett's test $(\mathrm{P}<0.05) .{ }^{1}$ Calcium intake $=\left(-1.29556 \times 10^{-7}\right) \mathrm{x}^{2}+0.00031672 \mathrm{x}+3.47654\left(\mathrm{R}^{2}=1.0\right) .{ }^{2}$ Calcium excretion $=-0.00013711 \mathrm{x}+$ $2.16317\left(\mathrm{R}^{2}=0.96\right) .{ }^{3}$ Calcium retention coefficient $=0.00422 \mathrm{x}+38.929\left(\mathrm{R}^{2}=0.97\right) .{ }^{4}$ Total phosphorus intake $=\left(-9.48148 \mathrm{x} 10^{-8}\right) \mathrm{x}^{2}+$ $0.00019431 \mathrm{x}+1.77815\left(\mathrm{R}^{2}=0.94\right) .{ }^{5}$ Total phosphorus excretion $=-0.00007276 \mathrm{x}+0.82110\left(\mathrm{R}^{2}=0.96\right)$. ${ }^{6}$ Total phosphorus retention coefficient $=-0.00000181 \mathrm{x}^{2}+0.00805 \mathrm{x}+53.9625\left(\mathrm{R}^{2}=0.83\right)$. 
lower Ca utilization (38.38\%) compared with the broilers fed with the positive control diet (50.11\%). According to TAMIM et al. (2004), the $\mathrm{Ca}$ of the diet can bind to phytate, forming calcium phytate, or to $\mathrm{P}$, forming calcium phosphates such as $\mathrm{Ca}_{3}\left(\mathrm{PO}_{4}\right)_{2}$. Thus, it is likely that the increase in the $\mathrm{Ca}:{ }_{\mathrm{av}} \mathrm{P}$ ratio from 2:1 (positive control diet) to 4:1 (negative control diet) worsened the $\mathrm{Ca}$ absorption due to a greater rate of complexation of $\mathrm{Ca}$ with the ${ }_{\text {av }} \mathrm{P}$, since the $\mathrm{Ca}{ }_{\text {phy }} \mathrm{P}$ ratio in the diets was kept the same (4:1). Moreover, limestone tends to increase the $\mathrm{pH}$ of the feed, especially during its passage through the intestine, favoring the formation of calcium phytate (SELLE et al., 2009). Thus, in the present study, an increase in the formation of calcium phytate might have occurred in the broilers fed diet containing $0.213 \%{ }_{\text {av }} \mathrm{P}$, because this diet has $84.2 \%$ more limestone than the positive control diet. Therefore, the increase in the formation rate of these insoluble complexes in the digestive tract of the broilers fed the negative control diet, without phytase, resulted in greater excretion of $\mathrm{Ca}$ followed by worsening of its coefficient of utilization.

Although the decrease in the $\mathrm{P}$ content of the diet has impaired the $\mathrm{Ca}$ absorption, this parameter was improved by increasing the phytase level in the diet, indicating that the more phytase is utilized greater will be its catalytic action on the phytic acid, thus reducing the power of complexation of its products from catalysis (myo-inositol phosphates with five or fewer phosphate groups) and thus allowing more free Ca to be utilized by the bird (SELLE et al., 2009). With the use of $2,250 \mathrm{FTU} \mathrm{\textrm {kg } ^ { - 1 }}$ of diet, the retention coefficient of $\mathrm{Ca}$ was similar to that determined for broilers fed with the positive control diet.

There was no interaction $(\mathrm{P}>0.05)$ between the level of phytase and sex for the balance and retention of ${ }_{\text {total }} \mathrm{P}$ (Table 3 ). However, males presented greater $(\mathrm{P}<0.01)$ intake, excretion and retention coefficient of ${ }_{\text {total }} \mathrm{P}$, corroborating to SCHOULTEN et al. (2002) who also verified that male broilers makes better use of P. Also following the trend verified to FI (Table 2), the ${ }_{\text {total }} \mathrm{P}$ intake was influenced of quadratic manner $(\mathrm{P}<0.05)$ by the phytase level in the diet, with the greatest ${ }_{\text {total }} \mathrm{P}$ intake estimated for the diet containing 1,025FTU kg-1 (Table 3). Besides, as expected, the diets formulated with $0.213 \%{ }_{\text {av }} \mathrm{P}$ promoted less ${ }_{\text {total }} \mathrm{P}$ intake than the positive control diet, according to Dunnett's test.

The decrease in the ${ }_{\text {av }} \mathrm{P}$ content of the diet from $0.426 \%$ to $0.213 \%$ (without the phytase supplementation) reduced the excretion of ${ }_{\text {total }} \mathrm{P}$ in 45.04\%; however, this parameter improved $(\mathrm{P}<0.05)$ even more by the increase in the phytase level in the diet, indicating that the greater supplementation of this enzyme promotes greater hydrolysis of phytate that results in the increase of the ${ }_{\text {phy }} \mathrm{P}$ utilization which, in turn, results in the lower excretion of ${ }_{\text {total }} \mathrm{P}$. Thus, the use of $2,250 \mathrm{FTU} \mathrm{kg}^{-1}$ of diet decreases the ${ }_{\text {total }} \mathrm{P}$ excretion in $56.75 \%$ when compared with what was observed for birds from the positive control group.

The utilization of ${ }_{\text {total }} \mathrm{P}$ was influenced $(\mathrm{P}<0.01)$ by the phytase level in the diet (Table 3 ), with the highest retention coefficient estimated for the diet containing 2,224FTU $\mathrm{kg}^{-1}$ of diet. This improvement in the retention of ${ }_{\text {total }} \mathrm{P}$ can be explained by the action of phytase on the phytate of the diet, as reported by several authors (HAN et al., 2009; SANTOS et al., 2011; GOMIDE et al., 2012), who verified gradual increase in the utilization of ${ }_{\text {phy }} \mathrm{P}$ in the function of the level of phytase in the diet.

\section{CONCLUSION}

Males presented greater feed intake, and better weight gain, feed conversion and total phosphorus utilization. Regardless of sex, when 2,250FTU $\mathrm{kg}^{-1}$ of diet formulated for broilers in the period from 15 to 28 days of age are used, it is possible to reduce the available phosphorus content from $0.426 \%$ to $0.213 \%$ without impairing performance, the tibia ash content and the retention coefficient of calcium, in addition to reducing the total phosphorus excretion in $56.75 \%$ and improving its utilization by birds in $38.58 \%$.

\section{ACKNOWLEDGEMENTS}

The authors would like to thank the Conselho Nacional de Desenvolvimento Científico e Tecnológico (CNPq), to Fundação de Amparo à Pesquisa do Estado de Minas Gerais (FAPEMIG) and to INCT-CA, for the financial support; and to the DSM company, for the supply of phytase.

\section{BIOETHICS AND BIOSSECURITY COMMITTEE APROVAL}

The present study was approved by Committee of Ethics in the Use of Animals (CEUA) of the Federal University of Lavras, under protocol number 004/11.

\section{REFERENCES}

AOAC (ASSOCIATION OF OFFICIAL ANALYTICAL CHEMISTS). Official methods of analysis. Maryland, 2005. 1094 p.

BERTECHINI, A.G. Monogastric nutrition. Lavras: UFLA, 2012. 373p.

FUKAYAMA, E.H. et al. Effect of phytase supplementation on performance and nutrient digestibility in diets of broilers. Revista Brasileira de Zootecnia, v.37, p.629-635, 2008. Available from: 
$<$ http://www.scielo.br/pdf/rbz/v37n4/07.pdf>. Accessed: Feb. 21, 2013. doi: 10.1590/S1516-35982008000400007.

GOMIDE, E.M. et al. Diets with reduced levels of nutrients supplemented with phytase and amino acids for broilers. Ciência e Agrotecnologia, v.36, p.100-107, 2012. Available from: <http:// www.scielo.br/pdf/cagro/v36n1/13.pdf $>$. Accessed: May, 25, 2013. doi: 10.1590/S1413-70542012000100013.

HAN, J.C. et al. Evaluation of equivalency values of microbial phytase to inorganic phosphorus in 22- to 42-day-old broilers. Journal of Applied Poultry Research, v.18, p.707-715, 2009. Available from: $\quad<$ http://japr.fass.org/content/18/4/707.full. pdf + html $>$. Accessed: Feb. 21, 2013. doi: 10.3382/japr.2009-00029.

JENDZA, J.A. et al. Efficacy and equivalency of an Escherichia coli-derived phytase for replacing inorganic phosphorus in the diets of broiler chickens and young pigs. Journal of Animal Science, v.84, p.3364-3374, 2006. Available from: <http://www. journalofanimalscience.org/content/84/12/3364>. Accessed: Feb. 21, 2013. doi: 10.2527/jas.2006-212.

MANANGI, M.K.; COON. C.N. Phytate phosphorus hydrolysis in broilers in response to dietary phytase, calcium, and phosphorus concentrations. Poultry Science, v.87, p.1577-1586, 2008. Available from: $<$ http://ps.fass.org/content/87/8/1577.full.pdf + html $>$. Accessed: May, 25, 2013. doi: 10.3382/ps.2007-00336.

MENDES, A.A. et al. Production of broiler chickens. Campinas: FACTA, 2004. 256p.

MENEGHETTI, C. et al. High levels of phytase in diets for broilers. Arquivo Brasileiro de Medicina Veterinária e Zootecnia, v.63, p.624-632, 2011. Available from: < http://www. scielo.br/pdf/abmvz/v63n3/v63n3a14.pdf>. Accessed: Feb. 21, 2013. doi:10.1590/S0102-09352011000300014.

RODRIGUES, P.B. et al. Effect of collection time and methodologies on the digestibility and energy value of poultry diets. Revista Brasileira de Zootecnia, v.34, p.882-889, 2005. Available from: $<$ http://www.scielo.br/pdf/rbz/v34n3/a21v34n3.pdf>. Accessed: Feb. 21, 2013. doi:10.1590/S1516-35982005000300021.

ROSTAGNO, H.S. et al. Brazilian table for poultry and pigs: food composition and nutritional requirements. Viçosa: Universidade Federal de Viçosa, 2005. 186p.

SAKOMURA, N.K.; ROSTAGNO, H.S. Research methods in monogastric nutrition. Viçosa: Universidade Federal de Viçosa, 2007. 283p.
SANTOS, L.M. et al. Calcium and available phosphorus levels in diets with phytase for broilers in the pre-starter and starter phases. Revista Brasileira de Zootecnia, v.40, p.24762485, 2011. Available from: <http://www.scielo.br/pdf/rbz/ v40n11/28.pdf>. Accessed: May, 25, 2013. doi: 10.1590/S151635982011001100028

SANTOS, F.R. et al. Effect of phytase supplementation in diets on nutrient digestibility and performance in broiler chicks. Journal of Applied Poultry Research, v.17, p.191-201, 2008. Available from: $<$ http://japr.fass.org/content/17/2/191.full.pdf + html $>$. Accessed: Feb. 21, 2013. doi: 10.3382/japr.2007-00028.

SAS (STATISTICAL ANALYSIS SYSTEM). System for Microsoft Windows, version 9.1.Cary, 2004.

SCHOULTEN, N.A. et al. Effect of the levels of calcium on the uptake of minerals in starter diets for broiler chickens supplemented with phytase. Ciência e Agrotecnologia, v.26, p.1313-1321, 2002.

SELLE, P.H. et al. Consequences of calcium interactions with phytate and phytase for poultry and pigs. Livestock Science, v.124, p.126-141, 2009. Available from: <http://www.sciencedirect.com/ science/article/pii/S1871141309000249>. Accessed: Feb. 21, 2013. doi: 10.1016/j.livsci.2009.01.006.

SHAW, A.L. et al. Assessment of an experimental phytase enzyme product on live performance, bone mineralization, and phosphorus excretion in broiler chickens. Journal of Applied Poultry Research, v.20, p.561-566, 2011. Available from: <http://japr.fass. org/content/20/4/561.full.pdf + html $>$. Accessed: Feb. 21, 2013. doi: $10.3382 /$ japr.2011-00389.

SIBBALD, I.R.; SLINGER, S.J. A biological assay for metabolizable energy in poultry feed ingredients together with findings which demonstrate some of the problems associated with the evaluations of fats. Poultry Science, v.59, p.1275-1279, 1963. Available from: <http://ps.fass.org/content/42/2/313.abstract>. Acessed: Feb. 21, 2013. doi: 10.3382/ps.0420313.

TAMIM, N.M. et al. Influence of dietary calcium and phytase on phytate phosphorus hydrolysis in broiler chickens. Poultry Science, v.83, p.1358-1367, 2004. Available from: <http://ps.fass. org/content/83/8/1358.long>. Accessed: Feb. 21, 2013.

WALK, C.L. et al. Extra-phosphoric effects of superdoses of a novel microbial phytase. Poultry Science, v.92, p.719-725, 2013. Available from: <http://ps.fass.org/content/92/3/719>. Accessed: May, 25, 2013. doi: 10.3382/ps.2012-02727. 